\title{
Clinicopathologic and prognostic features in appendiceal malignancies: does tumor invasiveness matter?
}

\author{
Kazım Şenol ${ }^{1,2}$ (ID), Murat Ferhat Ferhatoğlư ${ }^{3}$ (ID), Deniz Tihan ${ }^{2,4}$ (ID) \\ ${ }^{1}$ Department of General Surgery, Uludağ University School of Medicine, Bursa, Turkey \\ ${ }^{2}$ Department of General Surgery, Bursa High Specialty Training and Research Hospital, Bursa, Turkey \\ ${ }^{3}$ Department of General Surgery, Okan University School of Medicine, Istanbul, Turkey \\ ${ }^{4}$ Department of Anatomy, Uludağ University School of Medicine, Bursa, Turkey
}

\begin{abstract}
Objective: To evaluate the survival rates of appendiceal tumors and prognostic factors affecting survival.

Material and Methods: Demographic features, tumor characteristics and pre- and post-operative outcomes of the patients were analyzed retrospectively. The study was performed according to the Helsinki declaration.

Results: Twenty-three of the 2840 specimens were investigated prospectively. Median age of the patients was 28 (range: 1-89) years, with a male ( $n=1730$, $60.9 \%)$ to female $(n=1110,39.1 \%)$ ratio of 1.55 . Pediatric group did not present appendiceal malignancy. Carcinoid tumors were reported in $17(0.59 \%)$ and adenocarcinoma was reported in $6(0.20 \%)$ patients. Multivariate analyses of the subtypes showed serosal invasion as an independent risk factor for mucinous and non-mucinous adenocarcinoma (HR: $-2.70,95 \% \mathrm{Cl}: 0.006-0.755, \mathrm{p}=0.029)$. Median follow-up time was 48 months (range: $28-61$ months) and disease specific survival rates of carcinoid tumors, mucinous- and non-mucinous adenocarcinomas were 36(95\% Cl 32-40), 30 (95\% Cl 13-46), 43 (95\% Cl 3055) months, respectively $(p=0.749)$. Factors affecting survival in the univariate analyses were advanced tumor stage, serosal invasion and tumor invasion depth. In multivariate analyses, tumor invasion depth was the only independent prognostic factor with poor survival rates in all subtypes of appendiceal malignancies ( $\mathrm{HR}=1.31$ (95\% Cl: 1.01-13.5), $\mathrm{p}=0.047)$.
\end{abstract}

Conclusion: Tumor subtype and tumor invasiveness are important risk factors for survival. Besides other treatment modalities, appendectomy still remains the survival benefit with better clinical outcomes.

Keywords: Appendectomy, appendicitis, appendiceal malignancies, appendiceal tumors

Cite this article as: Senol K, Ferhatoğlu MF, Tihan D. Clinicopathologic and prognostic features in appendiceal malignancies: does tumor invasiveness matter? Turk J Surg 2019; 35 (4): 245-251.

\section{Corresponding Author}

Kazım Şenol

E-mail: kazimsenol@hotmail.com

Received: 30.01 .2018

Accepted: 13.03 .2018

Available Online Date: 16.12.2019

o Copyright 2019 by Turkish Surgical Society Available online at www.turkjsurg.com

DOI: $10.5578 /$ turkjsurg.4104

\section{INTRODUCTION}

Acute appendicitis is still the most frequent abdominal pathology requiring emergent surgery worldwide $(1,2)$. Its approximate lifetime prevalence has been reported as $8 \%$ (2). The annual incidence of this pathology is about $0.1 \%$ in Western countries (2-4).

The most common pathogenesis of acute appendicitis is the luminal obstruction of the appendix by a fecalith (2). However, all causes which may -directly or indirectly- obliterate the appendiceal cavity will lead the patient to an acute appendicitis. Appendiceal tumors are relatively rare but, likely, malignant appendiceal tumors may also obliterate the appendix lumen (5).

Despite extensive usage of antibiotics, appendectomy has been considered the standard treatment of appendiceal acute inflammation for decades $(1,2)$. Nowadays, the primary treatment approach is still surgery. Generally, open or laparoscopic removal of the appendix is the main aim of the surgical procedures. On the other hand, regarding the literature, surgical management still remains unclear in appendiceal malignancy (6).

This study aimed to discuss the management of malignant disease of the appendix in the light of our case series data. 


\section{MATERIAL and METHODS}

This retrospective clinical study was conducted in the Department of General Surgery, Bursa Yuksek Ihtisas Training and Research Hospital and Bursa State Hospital. Histopathological examination of 2840 specimens obtained from patients who had undergone appendectomy between January 2012 and December 2015 were investigated retrospectively. Twenty-three of these 2840 specimens were diagnosed as appendiceal malignancies. In total, the data of 23 patients were analyzed in terms of age, gender, preoperative and postoperative clinical parameters. Overall survival rates of the patients and prognostic parameters affecting survival were also evaluated. The study was performed according to the Helsinki Declaration.

\section{Statistical Analysis}

In descriptive analyses, mean \pm standard deviation was used for data following normal distribution and median and minimum-maximum values for non-parametric data. Non-parametric values were compared using Mann-Whitney U test. Comparison of categorical variables such as data of gender and histopathology was conducted using Fisher's exact and chi-square tests. Factors identified as significant in the univariate analyses were included into the multivariate logistic regression analysis.

Patients were followed up for 5 years after surgery. Death records were completed until January, 2016. Overall survival (OS) was measured until the date of death from any cause. The relationship between clinicopathological characteristics and OS was examined by Kaplan-Meier log-rank survival analyses and univariate Cox proportional hazards regression to calculate hazard ratios (HR) and 95\% confidence intervals (95\% Cl). Variables statistically significant ( $p$ value $<0.20$ ) were entered into a multivariate model using an entered method. The relationship between survival and prognostic parameters was examined using the $X^{2}$ method for linear trend. In all statistical tests conducted as part of the study, a value was taken as 0.05 and $p<0.05$ was considered statistically significant. Statistical analyses were performed using SPSS (Statistical Package for the Social Sciences ver. 21.0, SPSS Inc, Chicago, Illinois, USA) computer program.

\section{RESULTS}

A total of 2840 patients' demographic, clinical data and pathology reports were analyzed retrospectively. Overall median age of the patients was 28 years (range 1-89 years) with a male ( $n=$ $1730,60.9 \%)$ to female $(n=1110,39.1 \%)$ ratio of 1.55 . Pediatric group aged between $1-6$ years $(n=73,2.6 \%)$, late pediatric group aged between $7-11$ years $(n=146,5.1 \%)$ and adolescents aged between 12-17 years $(n=228,8 \%)$ did not present appendix tumors. Carcinoid tumors were reported in 17 (0.59\%) patients. Adenocarcinoma of the appendix was reported in $6(0.20 \%)$ patients, in whom $3(0.1 \%)$ of the tumors were with mucinous histology. Median age of the patients was 36 years (range: 19-71 years) in the carcinoid group and 51 years (range: 41-68 years) in the adenocarcinoma group. Patients with carcinoid tumors were significantly younger than patients with adenocarcinoma ( $p=$ 0.01). Carcinoid tumors were mostly located on the apex of the appendix in 9 (52.9\%) patients while 5 (29.4\%) tumors were located at the base and 3 (17.6\%) tumors were located at the body of the appendix. Mean tumor size of the carcinoid group (9.47 $\pm 5.83 \mathrm{~mm}$ ) was significantly smaller than the adenocarcinoma group (16 $\pm 3.90 \mathrm{~mm}, \mathrm{p}=0.02)$. Histopathology revealed that all of the adenocarcinomas were originated from adenoma. In the adenocarcinoma group, except 1 (16.6\%) submucosal mucinous tumor (T1NOM0), 5 (83.3\%) patients were presented with serosal invasion (T4NOM0). In the carcinoid group, mucosal and sub-mucosal invasion was present in 2 (11.76\%) patients, lamina muscularis propria invasion was present in 5 (29.41\%) patients and sub-serosa and serosa invasion was present in 4 (23.52\%) patients. Patients with adenocarcinoma were significantly more likely to have tumor extension beyond the appendix, whereas patients with carcinoid tumors tended to be limited to the appendix $(p=0.05)$. Mucinous/non-mucinous adenocarcinoma histology interpretations also showed significant serosal $(p=$ 0.05 ) and mesoappendix invasion $(p=0.002)$. All patients in the adenocarcinoma group and 4 (23.52\%) patients in the carcinoid group with mesoappendix invasion underwent right hemicolectomy procedure $(p=0.002)$. Multivariate analyses of statistically significant factors in the univariate analyses presented serosal invasion as a sole independent risk factor for mucinous and non-mucinous adenocarcinoma group (HR: $-2.70,95 \% \mathrm{Cl}$ : 0.006-0.755, $p=0.029$ ). Tumor characteristics of the patients are summarized in Table 1 and Table 2.

Median follow-up time was 48 months (range: 28-61 months). All patients were alive and disease free since the last follow-up. Estimated median survival rates of the carcinoid tumors, mucinous and non-mucinous adenocarcinomas were 48 (95\% Cl: 44-52), 55 (95\% Cl: 42-68), and 42 (95\% Cl: 26-58) months, respectively. Additionally, disease specific survival rates of carcinoid tumors, mucinous and non-mucinous adenocarcinomas were 36 (95\% Cl: 32-40), 30 (95\% Cl: 13-46), and 43 (95\% Cl: 30-55) months, respectively $(p=0.748)$.

Univariate analyses demonstrated that serosal invasion ( $p=$ $0.129)$, advanced tumor stage (TNM) $(p=0.108)$ and tumor invasion depth ( $p=0.179)$ were associated with poor survival rates. In multivariate analyses, tumor invasion depth was the only independent prognostic factor affecting survival ( $\mathrm{HR}=1.31$ (95\% Cl: 1.01-13.5), $p=0.047)$. The relationship between clinicopathological characteristics and survival is shown in Table 3.

\section{DISCUSSION}

Appendiceal tumors are broadly classified as epithelial and non-epithelial tumors. Epithelial tumors include adenoma, mucinous tumors with uncertain malignant potential and adeno- 


\begin{tabular}{|c|c|c|c|c|c|c|c|c|c|}
\hline Case & Gender & Age & Operation & $\begin{array}{l}\text { Tumor size } \\
(\mathrm{mm})\end{array}$ & Localization & Pathology & TNM & $\begin{array}{l}\text { Follow up } \\
\text { (months) }\end{array}$ & Recurrence \\
\hline 1 & Female & 28 & CA & 5 & Apex & Carcinoid tumors & Muscularis & 59 & None \\
\hline 2 & Male & 23 & CA & 10 & Distal & Carcinoid tumors & Subserosa & 58 & None \\
\hline 3 & Female & 71 & CA & 11 & Apex & Carcinoid tumors & Mucosa & 53 & None \\
\hline 4 & Female & 44 & CA & 7 & Apex & Carcinoid tumors & Subserosa & 52 & None \\
\hline 5 & Male & 40 & CA & 2 & Apex & Carcinoid tumors & Muscularis & 47 & None \\
\hline 6 & Female & 37 & $\mathrm{RHC}$ & 17 & Distal & Carcinoid tumors & Subserosa & 47 & None \\
\hline 7 & Female & 34 & CA & 6 & Apex & Carcinoid tumors & Subserosa & 46 & None \\
\hline 8 & Male & 23 & CA & 3 & Distal & Carcinoid tumors & Submucosa & 44 & None \\
\hline 9 & Male & 19 & CA & 6 & Apex & Carcinoid tumors & Submucosa & 43 & None \\
\hline 10 & Female & 24 & CA & 8 & Apex & Carcinoid tumors & Muscularis & 38 & None \\
\hline 11 & Male & 36 & CA & 22 & Body & Carcinoid tumors & Muscularis & 35 & None \\
\hline 12 & Male & 40 & CA & 4 & Apex & Carcinoid tumors & Muscularis & 31 & None \\
\hline 13 & Female & 24 & CA & 3 & Apex & Carcinoid tumors & Mucosa & 26 & None \\
\hline 14 & Female & 28 & CA & 12 & Body & Carcinoid tumors & Serosa & 59 & None \\
\hline 15 & Male & 41 & $\mathrm{RHC}$ & 13 & Distal & Carcinoid tumor & Serosa & 57 & None \\
\hline 16 & Male & 55 & $\mathrm{RHC}$ & 15 & Distal & Carcinoid tumor & Serosa & 42 & None \\
\hline 17 & Female & 55 & $\mathrm{RHC}$ & 17 & Body & Carcinoid tumor & Serosa & 39 & None \\
\hline 18 & Male & 68 & $\mathrm{RHC}$ & 21 & Distal & $\begin{array}{c}\text { Non-Muscinous } \\
\text { AC }\end{array}$ & Serosa & 55 & None \\
\hline 19 & Male & 54 & $\mathrm{RHC}$ & 17 & Distal & $\begin{array}{c}\text { Non-Muscinous } \\
\text { AC }\end{array}$ & Serosa & 53 & None \\
\hline 20 & Female & 48 & $\mathrm{RHC}$ & 13 & Distal & $\begin{array}{c}\text { Non-Muscinous } \\
\text { AC }\end{array}$ & Serosa & 45 & None \\
\hline 21 & Female & 41 & $\mathrm{RHC}$ & 12 & Body & Mucinous AC & Submucosa & 30 & None \\
\hline 22 & Female & 60 & $\mathrm{RHC}$ & 20 & Apex & Mucinous AC & $\begin{array}{c}\text { Surrounding } \\
\text { tissue }\end{array}$ & 55 & None \\
\hline 23 & Male & 49 & $\mathrm{RHC}$ & 13 & Apex & Mucinous AC & Serosa & 40 & None \\
\hline
\end{tabular}

carcinoma (7). Appendiceal adenocarcinomas represent 4-6\% of the overall appendiceal malignancies and are notably rare tumors (8). Primary appendiceal adenocarcinomas are mostly seen in sixth and seventh decades of life with an equal male-female ratio (9). Presentation of appendiceal adenocarcinomas differs in the clinical setting. The tumor should be presented as an incidental finding following acute appendicitis, as a pelvic mass or as peritoneal carcinomatosis with or without ascites (10). Acute appendicitis is the most common presentation (11). Therefore, there have been difficulties to determine the most appropriate classification system while defining appendiceal adenocarcinomas (12). There is no designated WHO (World Health Organization) and AJCC (America Joint Commission on Cancer) staging systems for all subtypes of primary appendiceal carcinomas regarding to the rarity of the disease (5). Pai and Longacre in 2005 classified appendiceal epithelial tumors into mucinous and non-mucinous (intestinal and signet ring cell) types (13). Mucinous adenocarcinoma represents $60 \%$ of all overall primary appendiceal adenocarcinomas, followed by intestinal-type adenocarcinomas and signet ring cell carcinomas (14). Whether the differences in tumor characteristics, tumor progression and overall-disease free survival rates suggest that all subtypes of appendiceal adenocarcinomas are distinct pathologies, to achieve the exact removal of the tumor with clear margins is determined as curative therapy. While simple appendectomy is described as a therapeutic method in local disease, adjunctive right hemicolectomy presented better survival rates (6). In our study, all patients in the adenocarcinoma group underwent right hemicolectomy procedure, but there was no significant survival benefit in between groups even though the median survival rate of the mu- 
Table 2. The relationship between clinical parameters and subtypes of appendiceal malignancies

\begin{tabular}{|c|c|c|c|c|}
\hline & $\begin{array}{l}\text { Carcinoid tumors } \\
\qquad(n=17)\end{array}$ & $\begin{array}{l}\text { Mucinous/Non-mucinous } \\
\text { adenocarcinoma } \\
(n=6)\end{array}$ & $\begin{array}{c}\text { P value, } \\
\text { Univariate analyses }\end{array}$ & $\begin{array}{c}\text { P value, } \\
\text { Multivariate analyses }\end{array}$ \\
\hline $\begin{array}{l}\text { Age, years } \\
\text { Mean (SD) } \\
\text { Range }\end{array}$ & $\begin{array}{c}36.59(13.94) \\
19-71\end{array}$ & $\begin{array}{c}53.33(9.58) \\
41-68\end{array}$ & 0.01 & - \\
\hline $\begin{array}{l}\text { Gender (\%) } \\
\text { Male } \\
\text { Female }\end{array}$ & $\begin{array}{l}8(34) \\
9(39)\end{array}$ & $\begin{array}{l}3(13) \\
3(13)\end{array}$ & 0.63 & - \\
\hline Tumor size, mm (SD) & $9.47(5.83)$ & $16(3.90)$ & 0.02 & - \\
\hline $\begin{array}{l}\text { Tumor Location (\%) } \\
\text { Distal } \\
\text { Body } \\
\text { Apex }\end{array}$ & $\begin{array}{l}5(21) \\
3(13) \\
9(39)\end{array}$ & $\begin{array}{l}3(13) \\
1(4) \\
2(8)\end{array}$ & 0.35 & - \\
\hline $\begin{array}{l}\text { Type of surgery (\%) } \\
\text { Appendectomy } \\
\text { Right hemicolectomy }\end{array}$ & $\begin{array}{l}13(76) \\
4(23)\end{array}$ & $6(100)$ & 0.002 & - \\
\hline $\begin{array}{l}\text { Tumor extension (No/Yes, \%) } \\
\text { Limited to appendix } \\
\text { Serosa invasion } \\
\text { Mesoppendix invasion } \\
\text { Vascular invasion } \\
\text { Perineural invasion }\end{array}$ & $\begin{array}{c}13 / 4 \\
12 / 4(23) \\
11 / 4(23) \\
11 / 6(35) \\
9 / 6(35)\end{array}$ & $\begin{array}{c}1 / 5 \\
1 / 5(83) \\
1 / 5(83) \\
2 / 4(66) \\
2 / 4(66)\end{array}$ & $\begin{array}{l}0.05 \\
0.05 \\
0.02 \\
0.19 \\
0.26\end{array}$ & $\begin{array}{c}- \\
0.029 \\
- \\
- \\
-\end{array}$ \\
\hline
\end{tabular}

Table 3. The relationship between prognostic factors and survival of patients with appendiceal malignancies following surgery

\begin{tabular}{|c|c|c|c|c|}
\hline Variables & $\begin{array}{c}\text { Univariate Analyses, } \\
\text { HR }(95 \% \mathrm{Cl})\end{array}$ & $\mathrm{p}$ & $\begin{array}{c}\text { Multivariate Analyses, } \\
\text { HR }(95 \% \mathrm{Cl})\end{array}$ & $\mathrm{p}$ \\
\hline Age $(15-40 y / 40-65 y />65 y)$ & $0.54(0.36-8.05)$ & 0.489 & - & - \\
\hline Gender (Male/Female) & $0.21(0.52-2.92)$ & 0.626 & - & - \\
\hline Tumor type (carcinoid/adenocarcinoma) & $0.12(0.42-2.98)$ & 0.805 & - & - \\
\hline Tumor site (base/body/apex) & $0.27(0.30-1.91)$ & 0.560 & - & - \\
\hline Tumor stage (TNM) & $1.96(0.64-7.86)$ & 0.108 & $0.23(0.76-2.11)$ & 0.361 \\
\hline Tumor invasion depth & $1.63(0.47-5.07)$ & 0.179 & $1.31(1.01-13.5)$ & 0.047 \\
\hline Meso-appendix invasion (no/yes) & $0.26(0.54-3.10)$ & 0.558 & - & - \\
\hline Vascular invasion (no/yes) & $0.33(0.60-3.21)$ & 0.430 & - & - \\
\hline Perineural invasion(no/yes) & $0.33(0.58-3.31)$ & 0.453 & - & - \\
\hline Serosal invasion (no/yes) & $0.70(0.81-5.04)$ & 0.129 & $0.45(0.33-7.36)$ & 0.561 \\
\hline Tumor perforation (no/yes) & $0.10(0.13-9.44)$ & 0.920 & - & - \\
\hline
\end{tabular}

cinous group was higher than the non-mucinous group. Similar to our findings, McCuskey et al. have mentioned in a review of 1061 cases that patients with mucinous and intestinal-type adenocarcinoma histology do not show any significant difference in survival rates (9). In the literature, peritonitis on diagnosis, histologic subtype, tumor grade, extent of surgery and pre-or per-operative peritoneal dissemination and intraperitoneal chemotherapy are well defined prognostic factors affecting survival and tumor recurrence (5,15-17). Besides these prognostic factors, including extended disease and age, aggressive 
tumor histology such as poorly differentiated adenocarcinomas and signet ring-cell type carcinomas are associated with 5-year survival rate of only $7 \%$ and worst prognosis $(14,18)$.

Non-epithelial tumors of the appendix are endocrine-carcinoid tumors, lymphoma and sarcoma. Unlike appendiceal adenocarcinomas, carcinoid tumors of the appendix are diagnosed at a much younger age of 32-42 years with female predominance $(14,19)$. However, there have been reports regarding a decrease of the overall percentage of appendiceal endocrine neoplasm among all gastrointestinal neuroendocrine tumors, and the prevalence of carcinoid tumors among all primary tumors of the appendix ranges between 43 and 57\% $(20,21)$. WHO has classified endocrine tumors according to histological differentiation and graded the tumors as benign and malignant well differentiated tumors and mixed exocrine-endocrine malignant tumors (goblet cell carcinoid) (22). Goblet cell carcinoid (adenocarcinoma) is also a rare tumor containing both epithelial and neuro-endocrine features with progressive clinical course in which $20-40 \%$ of the cases presented with early nodal involvement (23). Appendectomy with clear margins is defined as sufficient surgical option for early-stage tumors of primary appendiceal malignancies except goblet cell adenocarcinoma. Locally advanced adenocarcinoma or carcinoid tumors and goblet cell adenocarcinoma have a relative indication for right hemicolectomy with completion of tumor staging. Localization and size of the carcinoid tumors are prognostic factors besides tumor differentiation. AJCC staging system for carcinoid tumors is based on tumor size but does not consider tumor invasion depth and tumor grade. Mitotic activity, mesoappendix and lymphovascular invasion are also independent prognostic factors for carcinoid tumors. Although serosal involvement is not interpreted as a risk factor for carcinoid tumors, meso-appendix invasion is presented with poor prognosis (24). ENETS (European Neuroendocrine Tumor Society) defined a staging system including these important histologic features, tumor grade and meso-appendix invasion (25).

This study showed how the clinicopathological characteristics of the tumor affect survival of the patients undergoing curative resection of appendiceal malignancies. These data support the routine histological sampling of the tumor, preoperative and postoperative clinical outcomes of the patients. In this study, surgical choice between tumor subtypes was not associated with poor clinical outcomes. Statistical analyses between tumor subtypes revealed that patients with adenocarcinoma presented with an advanced age, larger tumor size and more extended disease at diagnosis. Carcinoid tumors were mostly located at the apex of appendix with local disease. As expected, presence of serosal invasion was referred as an independent high-risk factor for patients with adenocarcinoma of the appendix. Although estimated median survival rates between tumor sub- types were in close range, there was no disease related death and recurrence during the follow-up in all subtypes of appendiceal malignancies. Survival rates of the patients between tumor subtypes were not statistically significant. Among all clinical and pathological parameters identified pre- and postoperatively, tumor invasion depth was found as a sole risk factor affecting survival. Increased tumor invasion was found to be associated with the decreased disease specific survival rates.

There are several limitations regarding the multicenter and retrospective nature of the study. Several surgeons and surgery departments participated and provided invaluable clinical and pathological data into the study. Interpretations of the pathological specimens differed among centers and in between pathologists. Unfortunately, there were no reports of signet ring cell carcinoma and goblet cell carcinoid tumors. Therefore, this study could not present the risk factors and survival rates of these group of tumors. Our study also suggests that cooperation between referral clinics in defining the confirmed histological outputs and processing the data prospectively should be more effective to get better clinical outcomes with more reliable data.

In conclusion, tumor subtype and tumor invasiveness is an important risk factor for survival in appendiceal malignancies. Besides that, surgical choice is not presented as an effective factor for improved clinical outcomes and survival rates. Appendectomy alone presents satisfactory results but complete staging of the tumor should always be considered. Further prospective studies are needed to evaluate the proper staging of the tumors.

Ethics Committee Approval: The study is retrospective. The study was performed according to the Helsinki Declaration.

Informed Consent: Not required in this study.

Peer-review: Externally peer-reviewed.

Author Contributions: Concept - K.Ş. D.T.; Design - K.Ş.; Supervision - K.Ş., D.T.; Resource - K.S., M.F.F., D.T.; Materials - K.Ş., M.F.F., D.T.; Data Collection and/ or Processing - K.S.; Writing Manuscript - K.Ş.; Critical Reviews - K.Ş., M.F.F., D.T.

Conflict of Interest: The authors have no conflicts of interest to declare.

Financial Disclosure: The authors declared that this study has received no financial support.

\section{REFERENCES}

1. Ehlers AP, Talan DA, Moran GJ, Flum DR, Davidson GH. Evidence for an antibiotics-first strategy for uncomplicated appendicitis in adults: a systematic review and gap analysis. J Am Coll Surg 2016;222:309-14. [CrossRef]

2. Bhangu A, Soreide K, Di Saverio S, Assarsson JH, Drake FT. Acute appendicitis: modern understanding of pathogenesis, diagnosis, and management. Lancet 2015;386:1278-87. [CrossRef]

3. Fagenholz PJ, de Moya MA. Acute inflammatory surgical disease. Surg Clin North Am 2014;94:1-30. [CrossRef] 
4. Memon ZA, Irfan S, Fatima K, labal MS, Sami W. Acute appendicitis: diagnostic accuracy of Alvarado scoring system. Asian J Surg 2013;36:144-9. [CrossRef]

5. Kelly KJ. Management of appendix cancer. Clin Colon Rectal Surg 2015;28:247-55. [CrossRef]

6. Ruoff C, Hanna L, Wanging Z, Guhulamullah S, Gotileb V, Saif MW. Cancers of the appendix: review of the literatures. ISRN Oncol 2011;2011:728579. [CrossRef]

7. Ramaswamy V. Pathology of mucinous appendicial tumors and pseudomyxoma peritonei. Indian J Surg Oncol 2016;7:258-67. [CrossRef]

8. Ko YH, Park SH, Jung CK, Won HS, Hong SH, Park JC, et al. Clinical characteristics and prognostic factors for primary appendiceal carcinoma. Asia Pac J Clin Oncol 2010;6: 19-27. [CrossRef]

9. McCusker ME, Cote TR, Clegg LX, Sobin LH. Primary malignant neoplasms of the appendix: a population-based study from the surveillance, epidemiology and end-results program, 1973-1998. Cancer 2002;94:3307-12. [CrossRef]

10. Shankar S, Ledakis P, El Halabi H, Gushchin V, Sardi A. Neoplasms of the appendix: current treatment guidelines. Hematol Oncol Clin North Am 2012:26:1261-90. [CrossRef]

11. Sugarbaker PH. Epithelial appendiceal neoplasms. Cancer J 2009;15:225-35. [CrossRef]

12. Misdraji J, Young RH. Primary epithelial neoplasms and other epithelial lesions of the appendix (excluding carcinoid tumors). Semin Diagn Pathol 2004:21:120-33. [CrossRef]

13. Pai RK, Longacre TA. Appendiceal mucinous tumors and pseudomyxoma peritonei: histologic features, diagnostic problems, and proposed classification. Adv Anat Pathol 2005;12:291-311. [CrossRef]

14. McGory ML, Maggard MA, Kang H, O'Connell JB, KO CY. Malignancies of the appendix: beyond case series reports. Dis Colon Rectum 2005:48:2264-71. [CrossRef]

15. Yan TD, Bijelic L, Sugarbaker PH. Critical analysis of treatment failure after complete cytoreductive surgery and perioperative intraperitoneal chemotherapy for peritoneal dissemination from appendiceal mucinous neoplasms. Ann Surg Oncol 2007;14: 2289-99. [CrossRef]
16. Benedix F, Reimer A, Gastinger I, Mrockowski P, Lippert H, Kube R, et al. Primary appendiceal carcinoma--epidemiology, surgery and survival: results of a German multi-center study. Eur J Surg Oncol 2010;36:76371. [CrossRef]

17. Overman MJ, Fournier K, Hu CY, Eng C, Taggart M, Royal R, et al. Improving the AJCC/TNM staging for adenocarcinomas of the appendix: the prognostic impact of histological grade. Ann Surg 2013;257:10728. [CrossRef]

18. Turaga KK, Pappas SG, Gamblin T. Importance of histologic subtype in the staging of appendiceal tumors. Ann Surg Oncol 2012:19:1379-85. [CrossRef]

19. Graham RP, NP Williams, West KA. Primary epithelial tumours of the appendix in a black population: a review of cases. World J Gastroenterol 2009;15:1472-4. [CrossRef]

20. Hatzipantelis E, Panagopoulou P, Sidi-Fragandrea V, Fragandrea I, Ko liouskas DE. Carcinoid tumors of the appendix in children: experience from a tertiary center in northern Greece. J Pediatr Gastroenterol Nutr 2010:515:622-5. [CrossRef]

21. Alexandraki Kl, Kaltsas GA, Grozinsky-Glasberg S, Chatzellis E, Grossman AB. Appendiceal neuroendocrine neoplasms: diagnosis and management. Endocr Relat Cancer 2016;23:27-41. [CrossRef]

22. Deschamps L, Couvelard A. Endocrine tumors of the appendix: a pathologic review. Arch Pathol Lab Med 2010;134:871-5.

23. Roy $P$, Chetty R. Goblet cell carcinoid tumors of the appendix: An overview. World J Gastrointest Oncol 2010;2:251-8. [CrossRef]

24. Dall'Igna P, Ferrari A, Luzzatto C, Bisogno G, Casanova M, Alaggio R, et al. Carcinoid tumor of the appendix in childhood: the experience of two Italian institutions. J Pediatr Gastroenterol Nutr 2005;40:216-9. [CrossRef]

25. Pape UF, Perren A, Niederie B, Gross D, Gress T, Costa F, et al. ENETS Consensus Guidelines for the management of patients with neuroendocrine neoplasms from the jejuno-ileum and the appendix including goblet cell carcinomas. Neuroendocrinology 2012;95:135-56. [CrossRef] 


\section{ORIJINAL ÇALIŞMA-ÖZET}

Turk J Surg 2019; 35 (4): 245-251

\section{Apendiks tümörlerinin klinikopatolojik ve prognostik özellikleri: tümör invazyon durumu} önemli mi?

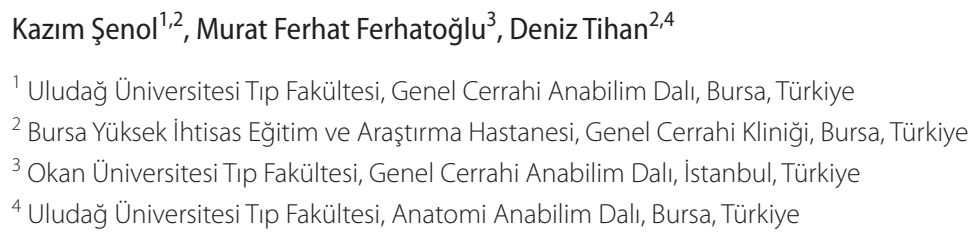

\section{ÖZET}

Giriş ve Amaç: Apendiks tümörlerinin sağkalım oranlarını ve sağkalımı etkileyen prognostik faktörü değerlendirmektir.

Gereç ve Yöntem: Olguların demografik özellikleri, tümör özellikleri ve ameliyat öncesi ve sonrası sonuçları retrospektif olarak incelendi. Hastaların sağkalımları kaydedildi. Çalışma Helsinki deklerasyonuna uygun olarak yapıldı.

Bulgular: Prospektif olarak 2840 spesmenin 23'ü incelendi. Hastaların medyan yaşı $28(1-89)$ erkek $(n=1730, \% 60,9)$ ve kadın $(n=1110, \% 39,1)$ oranı 1,55 idi. Pediatrik hasta grubunda apandisyel malignite gözlenmedi. On yedi $(\% 0,59)$ hastada karsinoid tümörler, $6(\% 0,20)$ hastada adenokarsinom tespit edildi. Alt grupların tek değişkenli analizlerinde yaş, tümör boyutu, operasyon tekniği, lokal hastalık, seroza ve mezoapendiks invazyonu gruplar arasında anlamlı derecede farklı bulundu. Subtiplerin çok değişkenli analizinde serozal invazyonun müsinöz ve non-müsinöz adenokarsinom için bağımsız bir risk faktörü olduğu gösterildi (HR: -2,70, \%95 GA: 0,006-0,755, p=0,029). Medikal takip süresi 48 aydı (aralık: 28-61 ay) ve karsinoid tümörler, müsinöz ve non-müsinöz adenokarsinomların hastalıklara özgül sağkalım oranları sırasıyla 36 (\%95 GA: $32-40$ ), 30 (\%95 GA: 13-46) ve 43 (\%95 GA: 30-55) ay arasında değişti ( $p=0,749)$. Tek değişkenli analizlerde sağkalımı etkileyen faktörler ilerlemiş tümör evresi, serozal invazyon ve tümör invazyon derinliği idi. Çok değişkenli analizlerde apandisyel malignitelerin tüm alt tiplerinde yetersiz sağkalım oranları olan tek tümör invazyonu faktörü [HR=1,31 (\%95 GA: 1,01-13,5), p=0,047] idi.

Sonuç: Tümör alt tipi ve tümör invazyonu sağkalımı belirlemede önemli risk faktörleridir. Diğer tedavi yöntemlerine göre apendektomi, daha iyi klinik sonuçlara ve artmış sağkalım oranlarına sahiptir.

Anahtar Kelimeler: Apendektomi, apendisit, apendiks maligniteleri, apendiks tümörleri

Doi: $10.5578 /$ turkjsurg.4104 